\title{
District Court Opinions that Remain Hidden Despite a Longstanding Congressional Mandate of Transparency - The Result of Judicial Autonomy and Systemic Indifference*
}

\author{
Peter W. Martin**
}

The E-Government Act of 2002 directed the federal courts to provide access to all their written opinions, in textsearchable format, via a website. Ten years later the Judicial Conference of the United States approved national implementation of a comprehensive database of those opinions through a joint venture between the courts and the Government Publishing Office (GPO). Despite the promise implicit in these initiatives, public access to many thousands of federal district court decisions each year remains blocked. They are effectively bidden. Many court websites lack a clear link to opinions, only a bare majority of district courts transmit decisions to the GPO, and far too many courts and judges fail to take the steps necessary for opinion distribution beyond the parties.

Using the large volume of district court Social Security litigation to measure and illustrate these failures, the article examines their dimensions, consequences, and causes. It concludes that the problem is a large one, that it poses a major challenge to those carrying out empirical studies and judicial analytics, and that the courts' radical decentralization combined with judicial autonomy will continue to frustrate goals of public access unless serious measures are taken at the national level. Finally, it argues that inclusion in the GPO database of federal judicial opinions should cease being optional.

\section{Introduction}

In the course of a year, nearly 300,000 civil actions ${ }^{1}$ and more than 75,000 criminal proceedings ${ }^{2}$ are begun in the U.S. District Courts, the federal judicial system's general-purpose courts of first instance. In resolving those matters, district judges and magistrate judges write and file many thousands of opinions. They range from rulings on preliminary motions to final judgments. ${ }^{3}$

Throughout the era in which lawyers, judges, and others seeking relevant case law searched in and read from print law reports, the federal government assumed no direct responsibility for the selection, collection, or publication of these decisions. Those tasks were performed in the private sector, most comprehensively by a publisher that worked so closely with the courts and their judges that many thought of its books as "official." In a functional, although not a legal, sense they were.

\footnotetext{
*C) Peter W. Martin, 2017. This work is licensed under the Creative Commons Attribution-NonCommercial-ShareAlike 3.0 License. To view a copy of this license, visit http://creativecommons.org/licenses/by-nc-sa/3.0/.

** Jane M.G. Foster Professor of Law, Emeritus, and cofounder, Legal Information Institute, Cornell Law School, Ithaca, New York

${ }^{1}$ Administrative Office of the U.S. Courts, U.S. District Courts - Civil Cases Filed, Terminated, and Pending, by Jurisdiction, Table C-3 (June 30, 2016), http:/ /www.uscourts.gov/report-names/statistical-tables-federal-judiciary. 2 Administrative Office of the U.S. Courts, U.S. District Courts - Criminal Defendants Filed, Terminated, and Pending (Including Transfers), Table D (June 30, 2016), http://www.uscourts.gov/report-names/statistical-tables-federaljudiciary.

3 The FDsys database of "written opinions" currently includes 115,503 from U.S. District Courts for the year 2016 . As will be explained shortly, that database is seriously incomplete.
} 
During that period, publication was highly selective. The volume of decisions and economics of publication made that a necessity. Moreover, unlike the decisions of the Supreme Court and Court of Appeals, none of these constituted precedent, in the strict sense. For any given district court opinion to be available as a reference for lawyers, judges, and others beyond the parties, the publisher had to view it as sufficiently important to warrant publication. Some district judges sought publication of their opinions. Others were indifferent. ${ }^{4}$ Publishers of looseleaf services covering particular areas of law in depth - environmental, intellectual property, or labor, for example routinely included district court decisions passed over by the editors of the general-purpose Federal Supplement reporter. Opinions disseminated in that fashion or even informally enjoyed no lesser authority.

Once the production and release of court documents shifted to electronic means filtering became logistically and economically unnecessary. The publication of legacy print reports continued, furnishing a familiar means of citation for those decisions appearing in their pages, but lawyers and judges ceased using those reports directly and limiting their district court case law research to the three thousand or so decisions put out in print each year. ${ }^{5}$

By the turn of the Twenty-First Century, the Internet had revealed itself to be a means of disseminating government-generated documents of unprecedented effectiveness. That led Congress, for the first time, to place responsibility for opinion publication directly on the district courts and all other federal courts. A provision of the E-Government Act of 2002 required federal courts to begin furnishing online access "to the substance of all written opinions ..., regardless of whether such opinions are to be published in the official court reporter." It set a deadline of April 2005 and specified that these online opinions had to be in "text-searchable format."7

At the time of the law's enactment, many federal courts were already doing much if not all that it required. The Supreme Court had gone online in April 2000 with a site that provided access to its decisions as released in slip opinion form, together with electronic replicas of 24 volumes of the U.S. Reports. ${ }^{8}$ All the U.S. Courts of Appeals were, by then, placing their "published" or precedential opinions at a web site. ${ }^{9}$ Although the district courts presented a more mixed picture, in late 2002 over half of them were providing online access to at least some decisions. ${ }^{10}$ The E-Government Act

\footnotetext{
${ }^{4}$ See Ellen Platt, Unpublished vs. Unreported: What's the Difference?, PERSPECTIVES: TEACHING LEGAL RESEARCH AND WRITING, Fall 1996, at 26, 27.

${ }^{5}$ Federal Supplement, Third Series (F. Supp. 3d) published by Thomson Reuters includes only 2816 district court decisions rendered during 2016. The publisher's companion Federal Rules Decisions (F.R.D.) contains an additional 22. Those counts are based on the Westlaw search "advanced: (judge) \& CI("F.Supp.3d") \%("not reported")" restricted to opinions dated between 1/1/2016 and 12/31/2016 and an equivalent search for "CI("F.R.D.").

${ }^{6}$ E-Government Act of 2002, 107 Pub.L. 347, \205(a)(5).

${ }^{7} \mathrm{Id}$.

8 See Supreme Court of the United States, http:// http://www.supremecourtus.gov/, as captured by the Internet Archive WayBack Machine on June 20, 2000; The Public Information Office, Supreme Court of the United States, Supreme Court to Implement Website (April 10, 2000), http://quux.org:70/Government/USA/Supreme\%20Court/scus/http/www.supremecourtus.gov_80/publicinfo/press /pr_04-10-00.html.

9 See Federal Law Materials - Judicial Opinions, http://www.law.cornell.edu:80/federal/opinions.html, as captured by the Internet Archive WayBack Machine on Oct. 13, 2002, https://web.archive.org/.

10 See Federal Law Materials - District \& Bankruptcy Courts, http://www.law.cornell.edu:80/federal/districts.html, as captured by the Internet Archive WayBack Machine on Oct. 14, 2002, https://web.archive.org/.
} 
gave federal courts that lagged in these developments over two years to catch up and set for all a standard of comprehensiveness and usefulness, not satisfied by the release of only selected or published or recent opinions or scanned images of paper documents.

Many, including some judges, imagined that act's requirement would dramatically improve access to the full range of federal decisions - for litigants, lawyers, and others. While a judge on the U.S. Court of Appeals for the Third Circuit, Supreme Court Justice Samuel A. Alito chaired the Advisory Committee on the Federal Rules of Appellate Procedure. In that capacity he led a lengthy study of the diverse circuit court rules governing the withholding of vast numbers of "routine" opinions from publication and limiting citation to such "unpublished" decisions. (Also sitting as a member of the same committee was a judge of the D.C. Circuit, now Chief Justice of the Supreme Court, John G. Roberts, Jr.) In the face of judicial resistance that ranged from mild to fierce, the committee recommended a new rule overturning all past circuit policies that forbade the citation of unpublished opinions. With some revision by the Judicial Conference of the United States and following a year's delay, the committee's recommendation was adopted as Rule 32.1 of the Federal Rules of Appellate Procedure. Responding to concerns about access to unpublished opinions, especially on the part of those unable or unwilling to pay the high prices of Lexis or Westlaw, Justice Alito's committee pointed to the E-Government Act. Said the report: "The disparity between litigants who are wealthy and those who are not is an unfortunate reality." But, it continued: "[T] he solution is found in measures such as the E-Government Act, which makes unpublished opinions widely available at little or no cost." 11

Over a decade later, effective and comprehensive access to district court decisions remains an elusive goal. ${ }^{12}$ Large numbers remain hidden from lawyers, academics, and the general public. This article explores the scope, consequences, and underlying causes of that largely unacknowledged reality.

\section{Consequences}

What is at stake? What is the harm if a good number, even thousands, of district court opinions remain out of sight, failing to make it to the surface? There are, after all, so many of them. Few are momentous. During the print era publication was the exception.

Unlike the U.S. Courts of Appeals, with the exception of a few mavericks, ${ }^{13}$ district court judges have never made a categorical distinction between their "published" and "unpublished" opinions. While no district court opinion constitutes "precedent" in the strict sense of being binding on either the deciding court or another court addressing the same question in a future case, all have the force of their persuasive power. That power is especially strong, it can be hoped, in similar cases coming before the same judge or court. In some fields, particularly those with few binding precedents

\footnotetext{
${ }_{11}$ Memorandum from Hon. Samuel A. Alito to Hon. David F. Levy, at 6 (May 6, 2005), http://www.uscourts.gov/sites/default/files/fr_import/AP5-2005.pdf.

12 While this article focuses on federal district court opinions, there is no reason to suppose that bankruptcy court decisions present a different picture.

13 See, e.g., Davis v. U.S., 944 F.Supp.2d 36 (D.D.C. 2013) (as the citation reveals a decision published in the Thomson Reuters Federal Supplement series despite being designated "not intended for publication"). For years many decisions of the U.S. District Court for New Jersey have been labelled "Not for Publication." See, e.g., Kendrick v. Guanci, No. 158354 (CCC) (D.N.J. Feb. 1, 2017) (available from both Google Scholar and Lexis). 
flowing down from court of appeals or Supreme Court decisions, individual district court decisions can exert great influence. In the current era, this can be so whether or not they were nominated by their author and selected by the publisher for inclusion in the print Federal Supplement series. ${ }^{14}$ Beyond their weight as authority, it is possible for district court opinions to hold significant value simply as tested templates for lines of legal argument.

Last and not least, opinions that resolve contested legal matters constitute data on judicial decisionmaking and lawyer effectiveness. In June 2017, LexisNexis announced the acquisition of the San Francisco start-up, Ravel Law. ${ }^{15}$ The transaction would, both parties declared, strengthen LexisNexis through the integration of Ravel's judicial analytics. To state the obvious, judicial opinions that are, as a practical matter, hidden from view cannot be analyzed for purposes of prediction or strategic decision-making. ${ }^{16}$ They are equally unavailable to academics or public bodies conducting empirical studies.

\section{Illustrating the Problem - One District Court, One Type of Case}

Each year the U.S. District Court for the Middle District of Florida receives approximately 850 civil complaints challenging rulings on benefit eligibility or amount by the Social Security Administration (SSA). Nearly 150 of them are filed with the court's Tampa division. Each is handled by one of six magistrate judges. When both parties consent, the assigned magistrate judge handles the case straight through to final judgment. If consent is withheld, the magistrate judge prepares a report and recommendation for the assigned district judge. Either party can object to that proposed resolution, but it is, more often than not, adopted in full. During 2016 over fifty Social Security appeals assigned to Magistrate Judge Anthony E. Porcelli were concluded. One concerned the denial of disability insurance benefits to James Thomas Ates. On August 1, 2016, Judge Porcelli issued an eight-page order in the Ates case, reversing the agency's decision. ${ }^{17}$ His order remanded the case to the Social Security Administration for further proceedings. Ted Taylor, the lawyer handling the appeal, was notified immediately by an email message generated by the court's electronic case management and filing system. He in turn notified Mr. Ates. It was good news for both. Ates

\footnotetext{
${ }^{14}$ Judged by citation count, notable examples include Almonte v. New York. State Div. of Parole, No. 9:04-CV-484 (GLS) (N.D.N.Y. Jan. 18, 2006) (which Shepard's counts as being cited 397 times, 34 of them warranting the label "followed") and Marquez.v. Colvin, No. 12 Civ. 6819 (PKC) (S.D.N.Y. Oct. 9, 2013) (cited 125 times according to Shepard's, followed 14).

15 LexisNexis Announces Acquisition of Ravel Law (June 8, 2017), https://www.lexisnexis.com/en-us/aboutus/media/press-release.page?id=1496247082681222. For more about Ravel's analytics, see Robert Ambrogi, Ravel Law Launches Court Analytics for Federal and State Courts, Law Sites (Dec. 5, 2016), http:/ /www.lawsitesblog.com/2016/12/ravel-law-launches-court-analytics-federal-state-courts.html.

16 The Lex Machina "Legal Analytics" products, also acquired by LexisNexis, all rest on federal court data. See Lex Machina, https://lexmachina.com/. Other vendors offering "legal analytics" services include Bloomberg Law. See New Bloomberg Law Litigation Analytics Solution Provides Insights into Judicial Behavior, Bloomberg BNA (Oct. 18, 2016), https://www.bna.com/new-bloomberg-law-pr57982078782/.

17 Ates v. Comm'r of Soc. Sec., No. 8:15-cv-1014-AEP (M.D. Fla. Aug. 1, 2016), http://www.access-tolaw.com/pacer/MDFla_15cv01014_08012016.pdf. Writing on this subject requires citing opinions unavailable from the standard online sources. Judge Porcelli's opinion in Ates and most of the others falling into this category can be retrieved by PACER subscribers at $\$ .10$ a page from that system via a direct link, in this instance:

https://ecf.flmd.uscourts.gov/doc1/047116358216. But having already located and retrieved these decisions, in each case incurring the fee, I have decided to place all of them online at an open site. That site is the target of the prior link and those provided for other "hidden opinions" throughout the article.
} 
could look forward, upon remand, to better than even odds of receiving benefits. ${ }^{18}$ For his attorney the decision opened the prospect of immediate compensation. Taylor promptly moved for an award of fees under the Equal Access to Justice Act. In an opinion dated September 7, Judge Porcelli ruled that the act's terms were met and awarded Ates and, by assignment, Taylor $\$ 4,365.90 .^{19}$

Although both Ates opinions clearly fall under the E-Government Act's access mandate, neither is available via a written opinion retrieval from the court's site. As a consequence, those researching Social Security cases on Lexis, Westlaw, Bloomberg Law, Casemaker, Fastcase, Google Scholar, and the rest remain ignorant of them. Such a database search does, however, retrieve a reversal and remand opinion in another Social Security denied benefits appeal filed only days before by Magistrate Judge Carol Mirando of the same court. ${ }^{20}$ What explains the difference?

Concededly, the commercial databases, Bloomberg, Lexis, Westlaw, and the rest, operate with different collection policies and systems. They are not compelled to offer all district court rulings. Of the major three, Westlaw has historically loaded fewer U.S. District Court opinions, a carryover from the high degree of selectivity required by the publisher's legacy print reporter. In recent years, though, competitive pressures have eroded that difference. Today, all major services have comparably extensive and, as this article will explain, comparably incomplete collections of Social Security claims decisions from the Middle District of Florida, collections in which the decisions of Magistrate Judge Porcelli are seriously underrepresented. ${ }^{21}$ The lack of access to his decisions in Ates and similar cases is neither an anomaly nor the consequence of quality or brevity filters imposed by online publishers. Its source lies within the federal judiciary. The problem is widespread.

Indeed, the situation is worse than the example of the Ates case suggests. Having been informed of the Ates decisions or having discovered them through laborious docket search, a researcher can retrieve both from the court's case management system. Any similar attempt to obtain the judge's report and recommendation in the case of Robinson-Rollins v. Commissioner of Social Security dated June 15, 2016, and adopted in full by District Judge Charlene Honeywell encounters the message "You do not have permission to view this document." Federal law is clearly to the contrary; but because someone at the court failed to tag the computer file holding the document properly, remote public access to it remains blocked. Similar lapses lie at the heart of the pervasive, but little noticed, case law access issue explored here.

\footnotetext{
${ }^{18}$ In 2007, the GAO calculated the rate of success upon remand at 66\%. U.S. Gov't Accountability Office, Report to Congressional Requesters, Disability Programs: SSA Has Taken Steps to Address Conflicting Court Decisions, But Needs to Manage Data Better on the Increasing Number of Court Remands, April 2007, at 16. 19 Ates v. Comm'r of Soc. Sec., No. 8:15-cv-1014-AEP (M.D. Fla. Sept. 1, 2016), http://www.access-tolaw.com/pacer/MDFla_15cv01014_09072016.pdf. Should Ates succeed in obtaining past due benefits upon remand, Taylor will be able to petition for a further award of up to $25 \%$ of total accrued past benefits minus the $\$ 4,365.90$, assuming that Taylor had a standard contingency fee agreement with Ates. See, e.g., Pretto v. Astrue, No.: 3:08cv397-LACEMT (N.D. Fla. Jan. 4, 2011, Feb. 4, 2011), http://www.access-to-law.com/pacer/NDFla_08cv00397_020042011.pdf. See generally Gisbrecht v. Barnhart, 535 U.S. 789 (2002).

${ }^{20}$ Watson v. Comm'r of Soc. Sec., No. 2:15-cv-185-FtM-CM (M.D. Fla. July 21, 2016), http://www. access-to-law/pacer/MDFla_15cv00185_07212016.pdf.

${ }^{21}$ Underrepresented but not totally absent. See, e.g., Schiffer v. Comm'r of Soc. Sec., No. 8:14-cv-2804-EAK-AEP (M.D. Fla. Feb. 11, 2016), http://www.access-to-law.com/pacer/MDFla_14cv02804_02112016.pdf. 
A lawyer filing a Social Security appeal with the District Court for the Middle District of Florida cannot know in advance to which magistrate judge the case will be assigned. However, upon learning to whom it has gone, that lawyer must decide whether to consent to having him or her conduct all proceedings and render a final judgment. Practice before the Social Security Administration might lead to an expectation that data bearing on the decision should be available. That agency regularly posts outcome statistics for each member of its cadre of over 1,200 administrative law judges. ${ }^{22}$ Their award percentages vary enormously. Those for the ALJs in the Tampa office range from a low of 28\% (ALJ Glen Watkins) to a high of 89\% (ALJ Paul Johnston). ${ }^{23}$

According to the Social Security Administration's internal data on judicial review of benefit denials the district court remand rate for Fiscal Year 2016 was slightly over 50\% nationwide. ${ }^{24}$ That number includes roughly 15\% remanded at the government's request, the result of a determination by SSA's Office of General Counsel that the administrative determination or process was, indeed, flawed. ${ }^{25}$ In a few cases, but only a few (perhaps $2 \%$ of the overall total), the district court remand is coupled with an outright reversal and simply directs the agency to calculate and pay benefits. ${ }^{26}$

A recent study by Harold Krent and Scott Morris concludes that in their rulings on Social Security cases U.S. district and magistrate judges exhibit even greater variability around average national figures than ALJs. Krent and Morris found that twenty-five percent of magistrate judges had remand rates below $22 \%$; twenty-five percent, over $56 \%{ }^{27}$ The mean was $40 \%$; the median, $50 \%$; the standard deviation, $21 \% .^{28}$

Whatever the national figures, an attorney with a case assigned to Judge Porcelli should want to know where his rulings place him along the spectrum reported by Krent and Morris. As noted above, an early decision that attorney must make is whether to consent to having Porcelli conduct all proceedings and render a final judgment. Withholding consent will not remove the magistrate judge from the case, but it will limit his role to producing a "report and recommendation" to which either party can object thereby putting the matter before an Article III U.S. district judge. ${ }^{29}$ To the extent that a full collection of a judge's opinions is not available, strategic choices on questions like these cannot be based on meaningful analytics.

\footnotetext{
22 See Social Security Administration, Hearings and Appeals, ALJ Disposition Data FY 2017, https://www.ssa.gov/appeals/DataSets/03_ALJ_Disposition_Data.html.

${ }^{23}$ Id.

24 See Social Security Administration, FY 2017 Congressional Justification, Table 3.34, at 169, https://www.ssa.gov/budget/FY17Files/2017FCJ.pdf.

25 See Jonah Gelbach \& David Marcus, A Study of Social Security Litigation in the Federal Courts, Administrative Conference of the United States, Final Report, July 28, 2016, at 31 (hereinafter ACUS Study).

26 See Social Security Administration, supra note 24.

${ }^{27}$ Harold J. Krent \& Scott Morris, Inconsistency and Angst in District Court Resolution of Social Security Disability Appeals, 67 HASTINGS L.J. 367, 389 (2016). In light of the current inquiry, the data source for these findings is noteworthy. The study relies on a data set consisting of all Social Security decisions held by Lexis rendered from 2010 through 2012 by federal district courts. The authors acknowledge that the total falls far short of the number of Social Security cases resolved during that period, but write that they had "no reason to doubt that the 10,743 cases analyzed [were] representative". Id. at 387-88. The research reported here throws a shadow over that premise.

${ }^{28}$ Id. at 389-91.

${ }^{29}$ In fiscal year ending September 30, 2016 the magistrate judges of the Middle District of Florida issued 178 Reports and Recommendations in Social Security cases. Table M-4B., U.S. District Courts-Reports and Recommendations Issued by U.S. Magistrate Judges Under 28 U.S.C. 636(b) During the 12-Month Period Ending September 30, 2016, http://www.uscourts.gov/data-table-topics/magistrate-judges.
} 
In preparing the necessary memorandum arguing that the administrative law judge decision should not be affirmed, access to Porcelli's opinions in the Ates case and others would allow counsel to argue for consistent treatment. Did the ALJ's decision in this later case fail to address the report of an examining psychologist that detailed the claimant's borderline IQ, limited ability to acquire new skills, poor cognitive processing, and recurring depression? If so, its facts would permit an argument that the case is "on all fours" with Ates and should, therefore, be remanded.

Court of appeals case law would, in all likelihood, frame that argument, but these are matters on which most U.S. Courts of Appeals provide only the most general guidance and little meaningful oversight. During the decade ending December 31, 2016 the 11th Circuit Court of Appeals (the appellate court that hears appeals from the Middle District of Florida) issued only eight precedential Social Security decisions; four of them affirmed the district court decision on appeal. ${ }^{30}$

There is an altogether different perspective on a magistrate judge's performance in resolving Social Security appeals and the other components of a full case load. Magistrate judges serve for a term of eight years. A full portfolio of opinions would appear to be relevant to their potential reappointment to a follow-on term or any subsequent nomination to some other public office.

Stepping back still further, academics and policy makers addressing such important and recurring questions as "Could the current approach to providing judicial review of Social Security disability determination be improved upon?" 31 are severely handicapped so long as they lack access to comprehensive data on the status quo.

\section{The Terms of the 2002 Transparency Mandate as Applied to the Courts}

The E-Government Act's opinion access requirement was one among a large and comprehensive set of measures aimed at improving federal government transparency and performance. The list of stated purposes included:

- providing increased opportunities for citizen participation,

- reducing costs and burdens for businesses and other Government entities,

- promoting better informed decision-making by policy makers, and

- making the Federal Government more transparent and accountable. ${ }^{32}$

The legislation led off with a finding that " $[\mathrm{m}]$ ost Internet-based services of the Federal Government are developed and presented separately, according to the jurisdictional boundaries of an individual department or agency, rather than being integrated cooperatively according to function or topic." For this reason, it required creation of and authorized appropriations for an integrated online information system covering all federal administrative agencies. ${ }^{33}$

\footnotetext{
${ }^{30}$ During the same period, the eleventh circuit decided another 400 or so Social Security disability cases, affirming the district court opinion in $85 \%$ of them. (Both tallies compiled by the author.)

31 See, e.g., Administrative Conference of the U.S., Special Procedural Rules for Social Security Litigation in District Court, Recommendation 2016-3, https:/ /www.acus.gov/recommendation/special-procedural-rules-social-securitylitigation-district-court.

32 See E-Government Act of 2002, 107 Pub.L. 347, \ 2.

33 See E-Government Act of 2002, 107 Pub.L. 347, \$ 204. The model had already been established. In 2000, a singleportal site for the federal government, FirstGov.gov, was opened by GSA. In 2007, it became USA.gov.
} 


\section{A. For the Judiciary, a Court by Court Rather Than a Consolidated Approach}

In sharp contrast, the act's section dealing with the judiciary left the federal courts as it found them - each responsible for the design, content, and maintenance of its own web site. The legislation addressed the courts individually rather than collectively, simply calling upon the chief judge of each and every one to bring the court's site up to the statute's minimum standards. These included the "[a]ccess to the substance of all written opinions" mandate. With one Supreme Court, twelve regional U.S. courts of appeals plus the federal circuit, ninety-four district courts, each with a companion bankruptcy court, and a single Court of Federal Claims, this directive invited a wide range of methods and degrees of compliance. For anyone conducting case research extending beyond a single circuit or district, the approach necessitated either: 1) resort to multiple sites, one per court, with nothing ensuring consistent approaches to case retrieval and document format or 2) reliance on a third-party service that had gathered and organized opinions from the many court sites. This was not an inconvenience experienced by the judges themselves, their clerks, or many of the lawyers appearing before them. They were already accustomed to having their case law research needs met by Westlaw and Lexis. The legislation's individual court site standards were for the benefit of an amorphous public.

The most obvious (although not most serious) gap between the act's explicit opinion-access requirement and the federal judiciary's indifferent performance is the absence of a well-marked link to opinions at many district court web sites. Figure 1 shows the home page of the Middle District of Florida site. Behind what door (tab or link) would a non-expert expect to find its opinions?

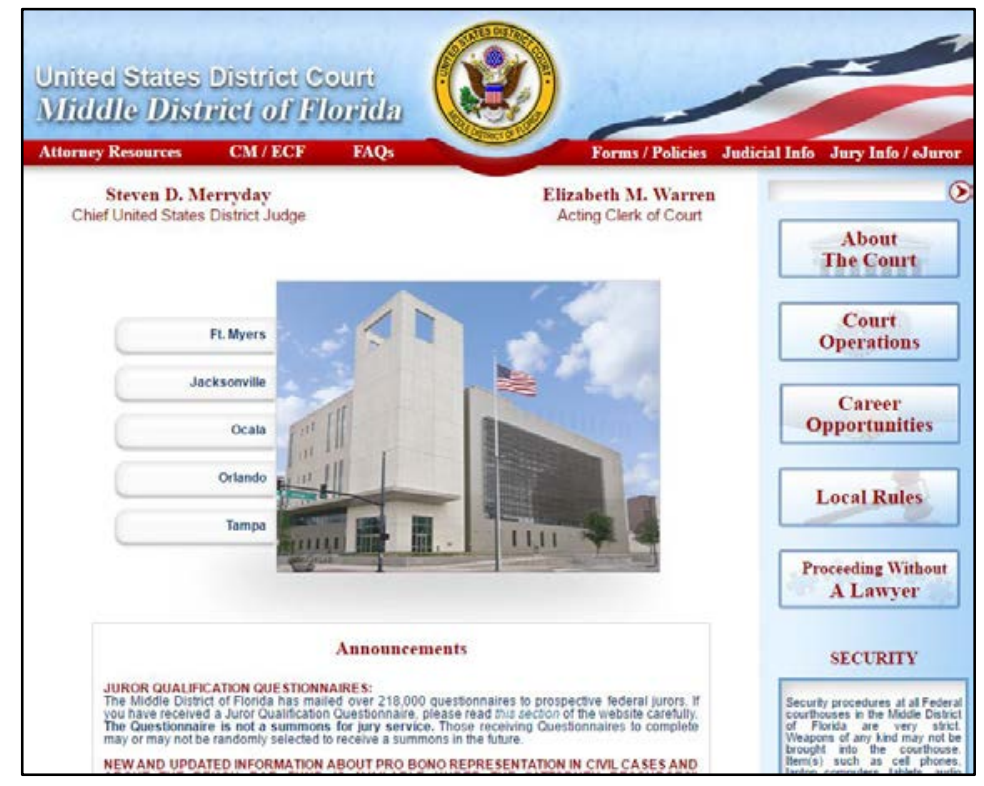

Figure 1 - Web Site of the U.S. District Court for the Middle District of Florida, https://www.flmd.uscourts.gov/

The page is typical in not having an "Opinions" link. Only 37 out of 94 do. Another 14 have a choice with that label on a drop-down menu under a home page tab, one that may be denominated 
"Judge's Info" 34 or "Case Info." 35 The Middle District of Florida site is far from alone in assuming that anyone seeking the court's opinions will know that the system named "PACER" is a means to that end and have a PACER account. (The court's PACER link appears under "Attorney Resources.") PACER, which stands for Public Access to Electronic Court Records, is the public access face of the federal electronic filing and case management software (CM/ECF) now installed in one version or another in all federal district courts. Its presence throughout the federal judicial system and accessibility from court web sites is, apparently, the ground on which the Administrative Office of the U.S. Courts certified to Congress in 2009 that all federal courts had achieved full compliance with the E-Government Act. ${ }^{36}$

That was just around the time that the inconsistency in design, functionality, and content of federal court web sites and, in particular, the difficulty in finding district court opinions through them led the Judicial Branch Committee of the Judicial Conference of the U.S. to commission the preparation of a website template. The resulting "District Court Website Toolbox" was distributed in early 2011. ${ }^{37}$ Use of the "toolbox" elements was totally elective. They were described as a set of tools "that courts may use when developing, enhancing, or updating their ... websites." 38 The homepage template included a prominent "Opinions" link, and distribution provided an occasion for reminding all district courts of the content required by the E-Government Act and Judicial Conference policy. ${ }^{39}$ As the data reported above reveal, the initiative's impact was limited.

A number of districts still maintain their own online opinion collections, apart from PACER. Some of these offer important functionality that PACER does not, such as the ability to search by year, judge, and words or phrases appearing in the text of an opinion (i.e. full-text search). ${ }^{40}$ Others provide more limited retrieval options. ${ }^{41}$

Well before enactment of the E-Government Act, the inefficiency of having each district court build and maintain its own opinion database had led the Administrative Office of the U.S. Courts to work with the one of the nation's busiest districts to establish a multi-court site it called CourtWeb. CourtWeb, begun with decisions from the Southern District of New York and running on its server, was designed to receive opinions from as many other district and bankruptcy courts as wished to participate. By the end of 1998, the Northern District of Illinois had joined. By the effective date of the E-Government Act in 2005, nine district courts and one bankruptcy court were using the

\footnotetext{
34 U.S. District Court for the Northern District of Alabama, http://www.alnd.uscourts.gov/.

35 U.S. District Court for the Middle District of Georgia, http://www.gamd.uscourts.gov/.

36 See Administrative Office of the U.S. Courts, The Third Branch, May 2009, at 1, http://www.hyperlaw.com/topics/2009/2009-05-Third-Branch--Courtwide-Compliance-with-E-Government-ActRequirements.pdf.

${ }^{37}$ Memoradum, From Judge. D. Brock Hornby, Chair, Committee on the Judicial Branch, \& James C. Duff, Director, Administrative Office of the U.S. Courts, Jan. 31, 2011, Re: District Court Website Toolbox (Information), http://legaltimes.typepad.com/files/fedct-memo.pdf. See Tony Mauro, Makeover Urged for Federal Court Sites, Law Technology News, Feb. 11, 2011 (Lexis)

${ }^{38} I d$.

39 See id.

40 See, e.g., U.S. District Court for the District of Connecticut, https://ecf.ctd.uscourts.gov/cgi-bin/Opinions.pl: U.S. District Court for the District of Kansas, https://ecf.ksd.uscourts.gov/cgi-bin/Opinions.pl.

41 See, e.g., U.S. District Court for the Southern District of Indiana, http://www.insd.uscourts.gov/court-opinions.
} 
system. ${ }^{42}$ Five years later the original host district withdrew from participation, and the database moved to the U.S. District Court for the Middle District of Pennsylvania. ${ }^{43}$ There it resides today, holding some decisions from seventeen district and eleven bankruptcy courts. ${ }^{44}$ For those ten of them that still actively use it, the site avoids the burden of maintaining a separate database. For the public, however, it offers neither a coherent collection of courts nor the assurance of completeness and currency as to those it includes. CourtWeb courts are scattered from Hawaii to Vermont, Alaska to Alabama. Sixteen appear to have ceased sending their opinions, although only one has indicated that fact at the site. Finally, reflecting the elective structure of the original design, its home page warns users that "not all opinions and rulings, even by participating judges, are necessarily posted to this [site]." In its current form CourtWeb is more likely to be a source of confusion than of assistance.

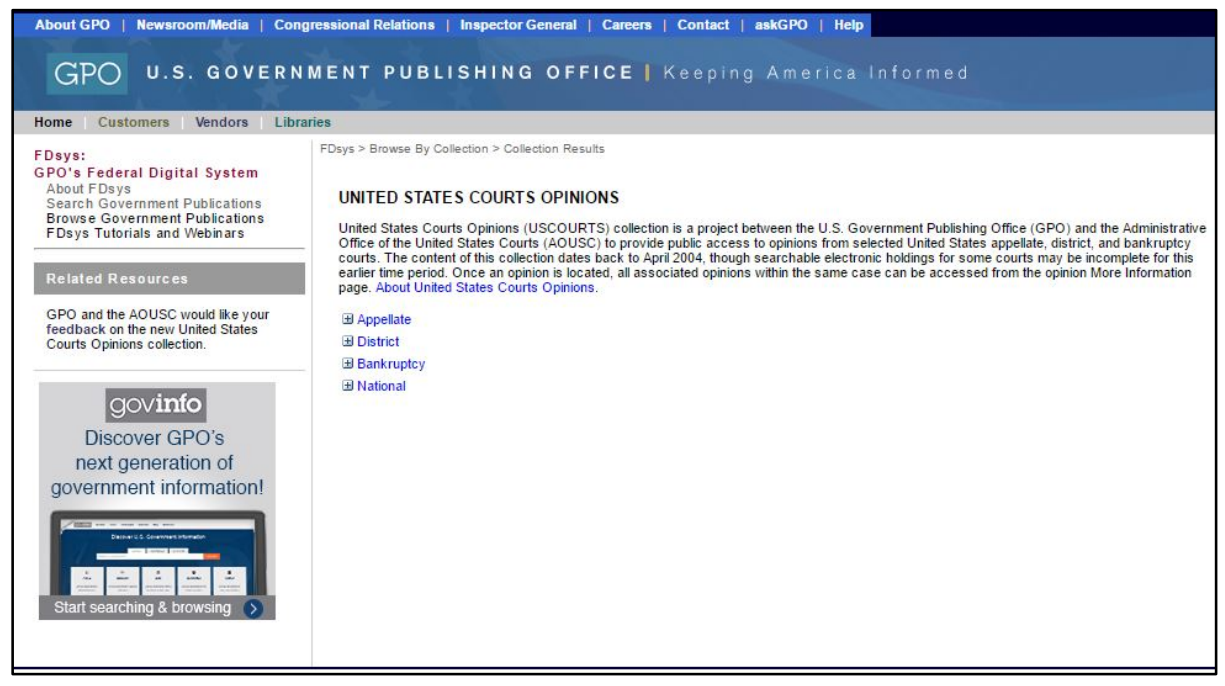

Figure 2 - FDsys, https://www.gpo.gov/fdsys/browse/collection.action?collectionCode=USCOURTS

A more recently established, and potentially more promising, public database of opinions from multiple district courts is now maintained by the Government Publishing Office (GPO). (See Figure 2.) As part of its Federal Digital System (FDsys) the GPO currently offers opinions from 51 federal district courts, 48 bankruptcy courts, all 12 regional circuit courts of appeals, and the Court of International Trade. (The collection does not include decisions of either the U.S. Supreme Court or the U.S. Court of Appeals for the Federal Circuit. Fifteen of the participating district and bankruptcy courts are or were users of CourtWeb.) Begun in 2011 as a small pilot project with only twelve participating courts, ${ }^{45}$ this joint venture was, a year later, approved for national

\footnotetext{
42 See Internet Archive: WayBack Machine, https://web.archive.org/web/20050611025855/http://www.nysd.uscourts.gov:80/courtweb/public.htm.

43 See Internet Archive: WayBack Machine, https://web.archive.org/web/20100303045457/http://www.nysd.uscourts.gov:80/courtweb.

${ }^{44}$ CourtWEB, http://courtweb.pamd.uscourts.gov/.

45 See Internet for Lawyers, Federal Court Opinions to be Available from Administrative Office of the Courts (AOC) and Government Printing Office (GPO) via FDSys, http://www.netforlawyers.com/content/free-searchable-federalcourt-opinions-available-via-gpo-access-fdsys-0022
} 
implementation by the Judicial Conference of the United States. "N6 "National implementation" means only that all federal courts are invited to participate, and have formally been "encouraged" by the Judicial Conference to do so. It does not mean that there is any process or set of incentives in place designed to obtain full participation. The decision as to whether or not to participate, like the responsibility for compliance with the E-Government Act's requirements, lies with the chief judge of each court. As the prior numbers indicate, five years after "national implementation" 43 district courts and 46 bankruptcy courts have not seen fit to join.

As the GPO receives opinions, it authenticates them, and loads the files into FDsys, along with their accompanying docket entries, exactly as they have come from each court. Unlike PACER, the system includes full-text search capability. However, the ability to retrieve opinions using full-text search depends on judicial compliance with another E-Government Act provision - namely, the requirement that opinions be provided in "text-searchable format." Astonishingly, twelve years after the act's effective date, some judges continue to have their decisions printed for review and signature and then scanned into $\mathrm{CM} / \mathrm{ECF}$ as PDF image files. ${ }^{47}$ According to a recent tally, six percent of the judicial documents designated as "written opinions" in 2016 were, for this reason, not "text-searchable." 48 Placed in FDsys as image files they remain utterly opaque to its search engine. As with other key aspects of E-Government Act observance, courts and judges vary enormously on this point. Over the past decade, the percentage of written opinions filed in non-text-searchable form has been more than cut in half, but during 2016 seven district courts had rates of nonsearchable opinions in excess of one-in-five. ${ }^{49}$ With some judges, the practice appears quite consistent. One of them is Senior Judge Edward J. McManus of the U.S. District Court for the Northern District of Iowa. During 2016 he filed at least 25 opinions on Social Security appeals, including one reversing and remanding a claim because of the Social Security Administration's failure to evaluate evidence of mental impairment submitted after the ALJ's determination of ineligibility but before a decision by the agency's Appeals Council. ${ }^{50}$ While those decisions are held in FDsys, none can be retrieved using an appropriately narrow word-search because all are scanned image files. ${ }^{51}$

At present, the FDsys opinion database is troubled by one further flaw. The regular transfer from each participating court's CM/ECF system is supposed to occur automatically. Nonetheless, interruptions can and do occur due to failure of the software designed to accomplish that, often the consequence of an upgrade. Such lapses can easily pass unnoticed at the court level as they have no direct effect on court functioning. Yet neither the Administrative Office nor the GPO has a system

\footnotetext{
46 See Report of the Proceedings of the Judicial Conference of the United States, Sept. 11, 2012, at 14, http://www.uscourts.gov/sites/default/files/2012-09.pdf.

47 The memorandum from the Administrative Office of the U.S. Courts detailing the requirements of the E-

Government Act for chief judges made it clear that "documents scanned into PDF" do not meet the Act's requirement of text searchability. See Memorandum from Leonidas Ralph Meacham to All Chief Judges, United States Courts, Nov. 10, 2004, Subject: Compliance with Website Requirements of the E-Government Act (INFORMATION).

${ }^{48}$ Email from Michael Lissner, Exec. Dir., Free Law Project (Aug. 11, 2017) (on file with author).

${ }^{49}$ Email from Michael Lissner, Exec. Dir., Free Law Project (Aug. 14, 2017) (on file with author).

50 Sabljakovic v. Colvin, No. 16-cv-2010 (N.D. Iowa Aug. 5, 2016), http:/ /www.access-tolaw.com/pacer/NDIowa_16cv02010_08052016.pdf.

51 The full set of decisions can be retrieved by party name, which in this instance includes the phrase "Social Security", and McManus's name because both are included in the docket entries associated with the opinions. While the opinions are not text-searchable, the docket entries and metadata are.
} 
in place to monitor opinion flow. Both were unaware in May 2017 that the most recent opinion from the Eastern District of Michigan in FDsys carried a 2013 date and that data transfers from a number of other courts had also fallen behind, although less egregiously. Those specific deficits have since been addressed, but no measures are in place to detect future interruptions of this sort.

In sum, because of the federal judiciary's radically decentralized approach to E-Government Act compliance, a curious citizen, lawyer, journalist, or scholar seeking to gather and analyze: 1) opinions on a particular issue, 2) opinions written by a specific judge, or 3) opinions written by a specific judge on a particular issue, may or may not find a court-based database that makes that possible and may or may not find the GPO's database a useful tool. Even where one of those options exists, the path to it may not be clearly indicated on the relevant court's web site.

\section{B. PACER's Queries and Reports as Compliance}

Thirty-two district courts, including the Middle District of Florida, neither participate in the GPO database nor offer their own searchable database of opinions. Are those courts in compliance with the E-Government Act? As already noted the act does direct that each court's opinions be made available in "text searchable" format. The phrase has, however, been interpreted by the Judicial Conference as requiring only that opinions be released as text rather than scanned image files, not that each court must assure access to its decisions via full-text search.

For federal courts that neither maintain nor cooperate with some other public database of their opinions, the PACER system furnishes the sole means of E-Government Act compliance. Yet PACER has serious deficiencies. Several are obvious. Any user of the Internet can go to the GPO's FDsys collection of federal court decisions, perform a search, and download the documents that meet its terms. No login is required. No fee is levied. By contrast PACER is a subscription service that runs on fees. Opinions may be exempt from them, but to gain access to free opinions one must subscribe.

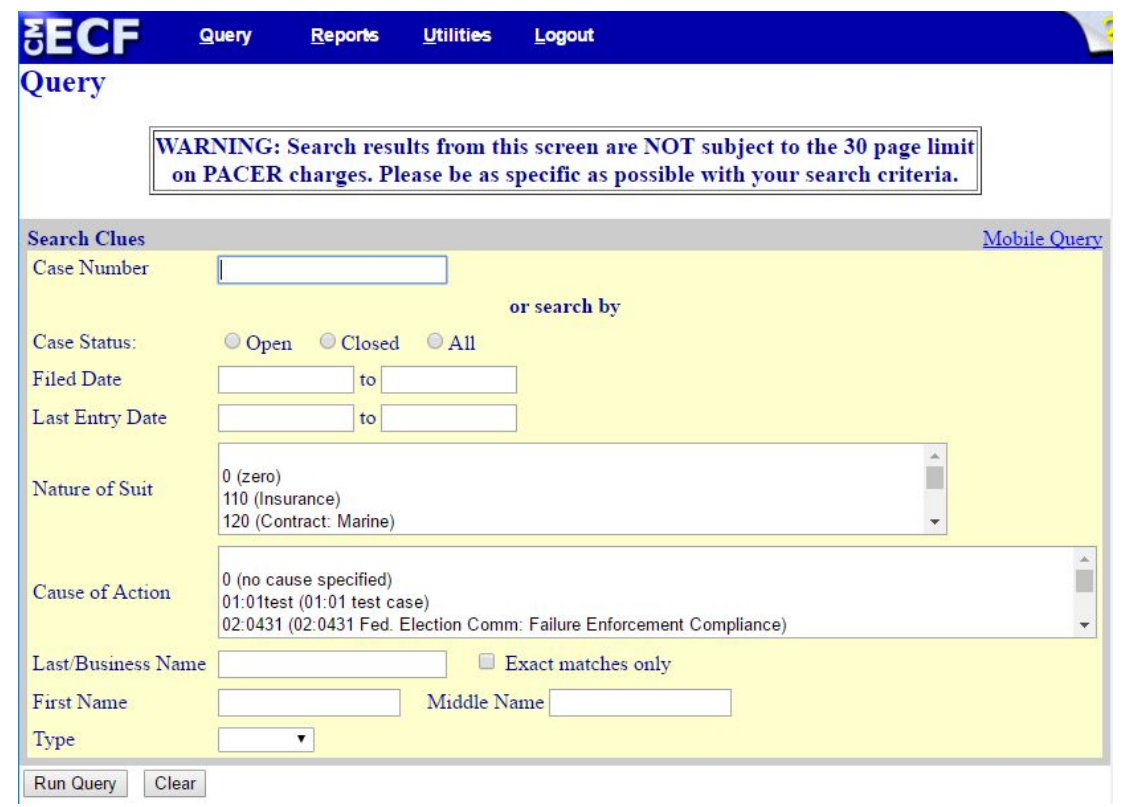




\section{Figure 3 - PACER (CM/ECF) Query form, U.S. District Court for the Middle District of Florida, https://ecf.flmd.uscourts.gov/cgi-bin/iquery.pl}

A member of the public, of whatever stripe (lawyer, journalist, academic, curious citizen, data vendor), who has obtained a PACER account and logged in to the Middle District of Florida's $\mathrm{CM} / \mathrm{ECF}$ system is delivered to a query form (Figure 3) that presents a warning and several unexplained options.

The warning is a reminder that unless one has been granted an exemption from PACER fees, searches and downloads carry a cost (currently $\$ .10$ per page). If one is searching for the documents pertaining to a single case, docket number, party names, and date can serve well. Suppose instead one is searching for Social Security disability decisions by Judge Porcelli. Conspicuous by its absence from PACER is any capacity to search by "name of judge." As recently as 2003 the Judicial Conference of the U.S. reaffirmed a long-standing policy prohibiting "the Administrative Office from releasing judge-identifying information from statistical databases." 52 In 2012, the suggestion the next generation of $\mathrm{CM} / \mathrm{ECF}$ (NextGen) should enable PACER users to access information by judge was tabled by a Judicial Conference subcommittee "for further study." 53

Enticingly the form does offer "Nature of Suit" and "Cause of Action" choices. The contents of those fields depend on categories selected by the party filing the complaint that initiated the action. The civil cover sheet contains a section in which the filer must mark off the single most appropriate "nature of suit" box. Those doing empirical work with federal case data have long commented on the imprecision of these designations - especially with types of litigation that can plausibly be fit in more than one of the available categories. ${ }^{54}$ The filer's indication of category is not effectively monitored by court staff and counts for nothing in the subsequent treatment of a case. Social Security appeals illustrate the difficulty. The "nature of suit" options include multiple Social Security categories. A complaint seeking review of a denial of Disability Insurance should be designated "863." However, mistakenly coding it as " 865 " will have no adverse effect on the case. Claims for Social Security Disability Insurance and Supplemental Security Income often overlap. Where they do either "863" or "864" would be an appropriate choice. Both cannot be selected. PACER documentation treats these "Nature of Suit" and "Cause of Action" categories as self-explanatory. The form available to the filers, who must afix them, does only a slightly better job. ${ }^{55}$

PACER predates the E-Government Act. Even in April 2005, at the point the act took effect for the judiciary, the electronic case management and case filing system (CM/ECF) to which PACER

\footnotetext{
52 See Report of the Proceedings of the Judicial Conference of the United States, March 18, 2003, at 20, http://www.uscourts.gov/sites/default/files/2003-03.pdf. Report of the Proceedings of the Judicial Conference of the United States, March 14, 1995, at 21-22, http://www.uscourts.gov/sites/default/files/1995-03_0.pdf.

53 See Administrative Office of the U.S. Courts, Additional Stakeholders Functional Requirements Group Final Report, Feb. 27, 2012, C-1.

54 See, e.g., Theodore Eisenberg \& Stewart Schwab, The Reality of Constitutional Tort Litigation, 72 CORNELL L. REV. 641, 653-54 (1987); Margo Schlanger, Inmate Litigation, 116 HARV. L. REV. 1555, 1699-1700 (2003).

55 U.S. Courts, Civil Cover Sheet, June 1, 2017, http://www.uscourts.gov/forms/civil-forms/civil-cover-sheet. One unique feature of the incomplete FDsys database is that it preserves these "Nature of Suit" tags as metadata. Since FDsys also permits full-text search of opinions, it allows case retrieval based, in part, on these categories, without forcing complete reliance on the accuracy of the filer's application of them. (None of the commercial research services retains this information.)
} 
provides access had not been installed in all federal courts. ${ }^{56}$ Where installed the system held and, through PACER, furnished public access to all documents filled in a case, including those written by the judge, however denominated. A highly configurable platform, CM/ECF allows courts to alter the names of events and document types to fit their distinctive terminology and procedures. As one judge, the chair of a committee charged with gathering the views of external users of this system, wrote in that committee's final report:

In fact, we are currently running some two hundred distinct case management systems in the federal courts, with little consistency as to which release is employed, which features are activated, and what naming conventions are used. The differences are often not apparent and are ill-explained. Our current systems work remarkably well when looked at through the lens of our individual courts; they are maddening to those users who attempt to work in or retrieve information from multiple courts. ${ }^{57}$

In response to the E-Government Act, the Administrative Office of the U.S. Courts, operating under Judicial Conference guidance, issued a new version of the CM/ECF software that, once installed by a court, incorporated two changes that applied to all documents in its system tagged as a "written opinion." The first exempted all documents so designated from PACER fees. Then and now access to the system still requires an account. Running a query that identifies a case or group of cases still gives rise to charges. Retrieval of a docket sheet listing and linking to all documents filed in a case does as well. But, by virtue of this 2005 software modification, downloading any of those documents tagged by the court as "written opinions" no longer does. ${ }^{58}$

Since the docket sheet itself does not show the designation, a second and more important change to PACER was the addition of a "Written Opinions Report." ${ }^{59}$ This operates only at the individual court level. To understand what that means, one must first understand that at bottom PACER is a set of queries and report options that can be used to access the docketed events and filings in cases held by any federal court's electronic case management and filing (CM/ECF) database. It is simply a feature of that court's distinctive CM/ECF installation.

The holder of a PACER account can go, one-by-one, to the CM/ECF systems of all 94 district courts and search for an individual case or for a set of cases filed between certain dates. The "Written Opinions Report" option added as district courts installed the version of CM/ECF released in 2005 allows retrieval of all documents designated as "written opinions" in cases meeting

\footnotetext{
${ }^{56}$ In November 2004, only 56 district courts were using CM/ECF. Memorandum from Leonidas Ralph Meacham to All Chief Judges, United States Courts, Nov. 10, 2004, Subject: Compliance with Website Requirements of the EGovernment Act (INFORMATION).

${ }^{57}$ See Administrative Office of the U.S. Courts, Additional Stakeholders Functional Requirements Group Final Report, Feb. 27, 2012 at iii.

58 See PACER Service Center, Announcements, July 2005, https://www.pacer.gov/announcements/quarterly/qa200507.pdf; CM/ECF Release Notes, Release 2.4, https://www.pacer.gov/documents/cmecf/relnotes/district_2.4.pdf; Electronic Public Access Fee Schedule, https://www.pacer.gov/documents/epa_feesched.pdf (Dec. 1, 2013).

59 See PACER Service Center, Announcements, July 2005, https://www.pacer.gov/announcements/quarterly/qa200507.pdf. 
the researcher's criteria. ${ }^{60}$ Use of that retrieval option as well as the downloading of any of the documents listed on the resulting report is free.

PACER has a second access point that it leads only to cases and not directly to opinions. The Administrative Office of the U.S. Courts maintains a national index kept up to date through regular take-offs from all individual court systems. ${ }^{61}$ Although this index permits searches across courts, it holds none of the docket listings or documents of the cases to which it points. Searches, other than those for a specific case identified by some combination of party name, docket number, and range of dates, are forced to rely on one or more of those elements, augmented, by one or more "Nature of Suit" and "Cause of Action" codes. Using that national index one can, for example, generate a linked list of all 107 actions filed from June 5 to June 8, 2017 naming Nancy Berryhill, the acting Commissioner of the Social Security Administration, as defendant or all 176 actions with one of the three principal Social Security "nature of suit" codes terminated during the same period. In either case the charge is ten cents a page of search results, and following a link to determine more about or search for documents filed in any of the listed cases takes the researcher to the PACER installation of the court in which the action was filed.

A few federal court sites that do not offer a full-text searchable database of the court's opinions explain these PACER options. Many more, including the site of the Middle District of Florida, do not. In any event, neither of PACER's entry points offers the individual researcher a useful set of tools for retrieving opinions addressing a specific issue or those written by a particular judge.

That reveals a fundamental truth about PACER. All spin aside, PACER is not and never has been designed for the ordinary citizen, scholar, or journalist wielding a web browser in pursuit of case information. The system's principal customers have long been "major commercial enterprises, large law firms, and financial institutions." ${ }^{62}$ It biggest single user is the U.S. Justice Department. ${ }^{63}$ Other heavy users fall into one of two main categories - experienced professionals involved in litigation with filings in the system ${ }^{64}$ and automated computer systems gathering documents and data, massive amounts of it, on a regular and recurring basis. Together, they are focused more on specific unfolding litigation or on what court filings reveal about individuals and business entities than on court opinions. Patently, the system was designed for such users and, for the most part, satisfies them. ${ }^{65}$ Thanks to these segments of the "public" PACER generates large sums that have been used

${ }^{60}$ Currently all district court CM/ECF systems include this report option. A handful of bankruptcy courts still do not.

${ }^{61}$ PACER Case Locator, https://www.pacer.gov/findcase.html.

${ }^{62}$ The quotation and the data appearing in this paragraph are drawn from a document entitled "Electronic Public Access Program" distributed at the Feb. 14, 2017 hearing of the Subcommittee on Courts, Intellectual Property and the Internet of the House Judiciary Committee by committee staff (copy on file with the author).

63 See Administrative Office of the U.S. Courts, Electronic Public Access Program Summary 5 (Dec. 2012), https://www.pacer.gov/documents/epasum2012.pdf.

${ }^{64}$ Litigants receive one free copy of all documents filed in their case through a link in the notice of filing generated by $\mathrm{CM} / \mathrm{ECF}$, but lawyers who rely on $\mathrm{CM} / \mathrm{ECF}$ as their own repository of events and documents in a case end up using PACER and paying PACER fees.

65 Surveys of user satisfaction find these heavy users relatively pleased with PACER although eager for more consistent configuration from court to court. Least satisfied are users in educational and research institutions. See Administrative Office of the U.S. Courts, The Third Branch, May 2010, at 3,

https://issuu.com/uscourts/docs/usct7651_third_branchmay; Administrative Office of the U.S. Courts, PACER Survey Shows Rise in User Satisfaction, June 25, 2013, http://www.uscourts.gov/news/2013/06/25/pacer-surveyshows-rise-user-satisfaction. 
to support a range of court technology projects. In recent years annual revenues have held steady at around $\$ 145$ million. (Figure 4) Close to $90 \%$ of the total comes from a tiny percentage of account holders $(2.7 \%){ }^{66}$

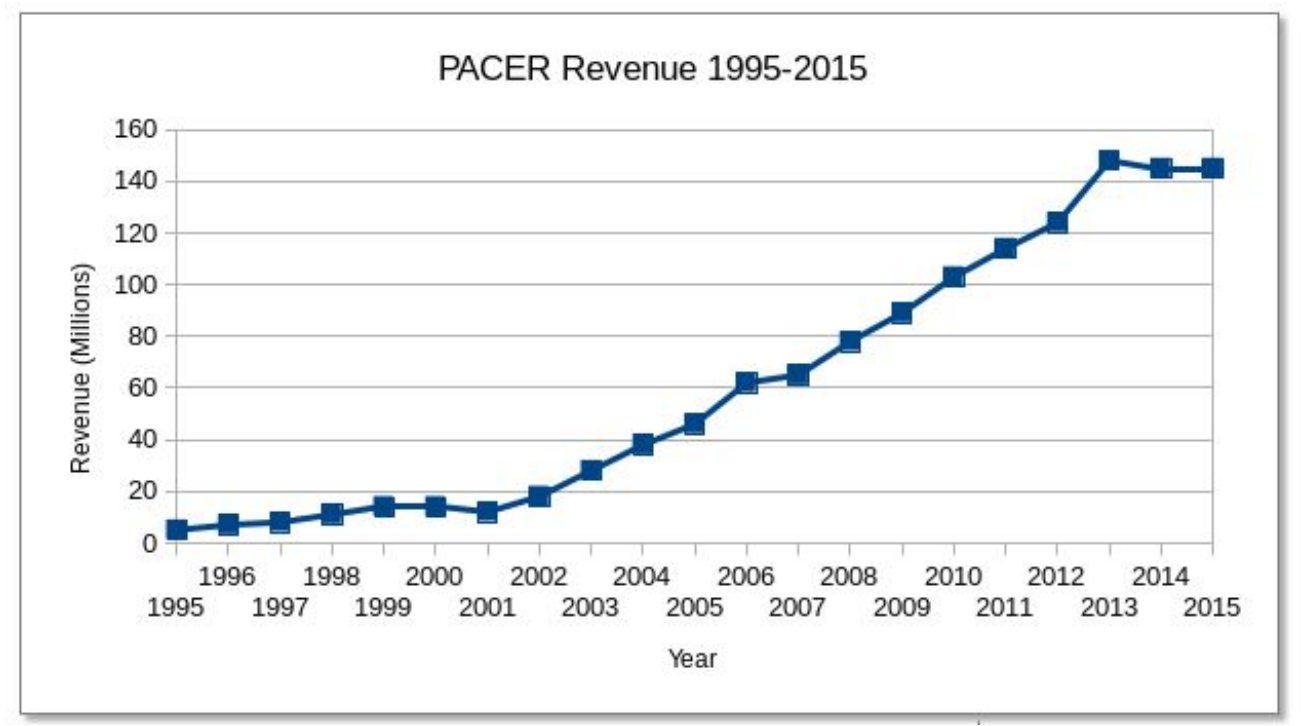

\section{Figure 4 - Free Law Project, How Much Money Does PACER Make?, https://free.law/2016/11/14/how-much-money-does-pacer-make/}

\section{PACER as an Opinion-Collection Tool for Third-Party Database Proprietors and the Data Feed for FDsys}

The impact of PACER's manifest indifference to citizen access has, in recent years, been alleviated by developments that could not have been foreseen when the "Written Opinions Report" was added in 2005. The most significant of these was Google's launch of a free and open, searchable, case law database. ${ }^{67}$ Thanks to Google Scholar's high profile entry into the legal information field in November 2009, and a subsequent small swarm of start-ups pursuing a business strategy of opening their primary law data to the public while providing premium services to subscribers, the access environment has changed dramatically. The inadequate and poorly documented search capabilities offered by individual federal courts no longer pose a practical access barrier so long as the courts' opinions can be easily and reliably collected by these new, open-to-the-public, systems. Using Google Scholar or Casetext, a citizen can, without charge or subscription, retrieve Social Security decisions of the Middle District of Florida, including, for example, Judge Porcelli's Report and Recommendation in Munger v. Colvin, No: 8:15-cv-2937-T-33AEP (M.D. Fla. Feb. 2, 2017). How do these free services and their fee-based competitors gather decisions from the federal district courts?

\footnotetext{
66 A class action challenging the extensive use of PACER revenues for non-PACER expenses was recently certified in the D.C. District. Since that district participates in FDsys, Judge Huvelle's opinions in the case can be found there, not to mention Google Scholar and the standard commercial services. See National Veterans Legal Services Program v. United States, No. 16-cv-00745-ESH (D.D.C. Jan. 24, 2017) (granting class certification), http:/ / www.access-tolaw.com/pacer/DDC_16cv00745_01242017.pdf; National Veterans Legal Services Program v. United States, No. 16-cv-00745ESH (D.D.C. Dec. 5, 2016) (denying defendant's motion for summary judgment), http:/ /www.access-tolaw.com/pacer/DDC_16cv00745_12052016.pdf.

${ }_{67}$ See Google, Official Blog, Finding the laws that govern us, Nov. 17, 2009, https://googleblog.blogspot.com/2009/11/ finding-laws-that-govern-us.html.
} 
PACER's “Written Opinions Report" is reasonably suited to their needs. Database proprietors have only to deploy software scripts that routinely and systematically run that report on each of the 94 district court systems to retrieve all tagged opinions filed since their last harvest.

For FDsys the process is functionally equivalent. The CM/ECF systems of participating courts automatically transmit all judicially prepared documents that have been tagged as "written opinions" to the GPO.

\section{At the Root of PACER's Failure - Courts and Judges that Do Not Take the Tagging of Written Opinions Seriously}

By this point it should be clear that it is not the lack of a searchable database of opinions on the Middle District of Florida web site or the court's failure to participate in FDsys that explains the absence of the Ates opinions from Google Scholar and Lexis. Both services hold reports and recommendations their author has written in other Social Security appeals, including the Munger case noted directly above. ${ }^{68}$

The Ates decisions and countless others remain hidden due to a lack of systematic attention to or oversight of how courts, individual judges, and court staff have implemented the E-Government Act's "written opinion" requirement. A large number of opinions issued by Judge Porcelli and other Middle District of Florida judges are not retrieved by a PACER "Written Opinions Report" simply because they have not been identified by the individual filing and docketing them as "written opinions."

The E-government Act places responsibility for compliance with its "written opinion" and other court web site mandates on each court's chief judge. PACER's implementation disperses it further by leaving the ultimate decision as to whether a particular document qualifies with its author or the court staff member docketing it using the "event" categories set up in his or her court's CM/ECF system.

Lurking behind that decision and the choice among available docketing categories is an obvious definitional question: Which of the myriad rulings, orders, judgments, and reports written and filed by judges are covered by the E-Government Act mandate? A memorandum to chief judges from the director of the Administrative Office of the U.S. Courts, dated Nov. 10, 2004, ${ }^{69}$ furnished guidance on that point, approved by the executive committee of the Judicial Conference:

For the purposes of the E-Government Act of 2002, ... [a] "written opinion" is defined as, "any document issued by a judge or judges of the court, sitting in that capacity, that sets forth a reasoned explanation for a court's decision." This definition is clarified by the following points:

\footnotetext{
68 See, e.g., Jasper v. Colvin, No. 8:16-cv-727-T-23AEP (Jan. 31, 2017), http:/ /www.access-tolaw.com/pacer/MDFla_16cv00727_01312017.pdf; Kubl v. Berrybill, No. 8:17-cv-394-T-33AEP (March 6, 2017), http://www.access-to-law.com/pacer/MDFla_17cv00394_03062017.pdf.

${ }^{69}$ Memorandum from Leonidas Ralph Meacham to All Chief Judges, United States Courts, Nov. 10, 2004, Subject:

Compliance with Website Requirements of the E-Government Act (INFORMATION). 
1. The responsibility for determining which documents meet this definition rests with the authoring judge, and the determination should be made at the time the document is filed;

2. The decision as to whether a document meets this definition is not the same as the decision about whether an opinion is to be published;

3. The definition is expressly intended to cover reports and recommendations issued by magistrate judges at such time as any action is taken by a district judge on a report and recommendations issued by a magistrate judge, and also includes a summary order adopting such report and recommendations;

4. The definition is not intended to include routine, non-substantive orders such as scheduling orders or rulings on motions for extension of time ...."70

A subsequent memorandum to all district, bankruptcy, and magistrate judges, dated April 7, 2005, announced the release of a new version of the CM/ECF software, incorporating two features designed to facilitate compliance. The first allowed the automatic tagging of specified categories of judicially authored documents "such as Memorandum Opinions," those categories to be set by each court. The second feature enabled a prompt querying the judge or "judicial assistant, law clerk, or courtroom deputy" filing a document of some other type whether it met the definition of a "written opinion." Both documents tagged automatically and those tagged as a result of an affirmative answer to that prompt would then be listed on and retrievable at no charge by means of a Written Opinions Report. ${ }^{71}$ The ultimate source of widespread E-Government Act non-compliance lies right there.

For these two new features to achieve the intended result, the software (or software update for those courts that already had CM/ECF installed) had to be configured by each court's administrative staff to correspond to local nomenclature and docketing procedures. Document titles and docketing terminology vary so widely from court to court that the standard settings in the software as released were and still are a poor fit for many. The category or categories resulting in automatic tagging have to be ones regularly used by the court for rulings that meet the "written opinion" definition. If not the software's "event dictionary" has to be adjusted to fit its practice. Other types of orders that may or may not qualify and therefore warrant a prompt asking whether the document being docketed constitutes a "written opinion" have to be identified and coded. Assuming appropriate adjustments to the docketing system, some form of communication between the authoring judge and members of court staff docketing a document that may be entitled "order," "memorandum," or "judgment" is necessary. The 2005 Administrative Office memorandum suggested several approaches, but all of them necessitated changes in court practice, practice that before 2005 had no compelling reason to single out this particular document category. Unless a court's docketing practice already distinguished among different types of judicial writing in a way that could readily be mapped onto categories warranting automatic or possible tagging as "written opinions" the new

${ }^{70} I d$. A fifth clause, not quoted, applied only to the Courts of Appeals.

${ }^{71}$ Memorandum from Leonidas Ralph Meacham to Judges, United States District Courts; Judges, United States

Bankruptcy Courts; United States Magistrate Judges, April 7, 2005, Subject: Compliance with the April 2005 E-

Government Act Requirements Regarding Access to the Substance of All Written Opinions Via CM/ECF (INFORMATION). 
CM/ECF features provided no straightforward means of E-Government Act compliance. Reports and recommendations by magistrate judges posed a particular challenge. Read narrowly the Judicial Conference guidance called for them to be tagged not when filed but only upon their adoption in whole or part. To achieve that result, orders adopting such recommendations had to be docketed as a separate category, with that event programmed to tag the corresponding magistrate judge's opinion retroactively.

The act placed no responsibility at the national level, and none has been assumed. Among the many reports issued by the Administrative Office of the U.S. Courts, none measures or can even be used to infer degrees of compliance. In the training and guidance furnished new judges and staff, there appears to be little or no attention devoted to this significant detail - how to file a distinct category of judicial writing, which may carry such diverse titles as "order," "memorandum," "judgment," "ruling," or "report and recommendation.,"72

\section{Probing the Problem Further}

\section{A. One District Court, One Type of Case}

District courts exhibit remarkably diverse interpretations and levels of internal compliance with the injunction to tag all written opinions. The range is suggested by their ratios of written opinions to closed civil cases. $^{73}$ In 2016 for the 94 district courts those ratios ranged from a high of 4.21 (i.e. an average of over four opinions per civil case) for the Eastern District of California to a low of .03 for the Southern District of Iowa (three opinions per one hundred cases), with a median of .69 (the Eastern District of Wisconsin). The Middle District of Florida fell below that mark with a ratio of .50 .

Some of the variance may be the result of differences in civil docket composition. As a control against that, one can compare courts and judges in terms of a specific type of case, ideally one with significant volume, minimal procedural complexity, a relatively standard set of issues, and a predictable number of opinions per case. Social Security cases qualify on all counts. They are filed at a rate in excess of 18,000 a year. Each comes to the district court as an appeal from an agency adjudication. The proceedings are limited to a review of the administrative record. The issues are limited to whether the Social Security Administration's proceedings and determination involved legal error or were not supported by substantial evidence.

Social Security cases have one additional attractive feature. A single federal agency, the Social Security Administration, participates in every such suit. As a result, there is a public data source other than the courts that can be used to benchmark PACER opinion counts. A recent study of Social Security litigation, prepared for the Administrative Conference of the United States, has, in fact, drawn upon data furnished by the Social Security Administration rather than the federal courts, to calculate the remand rates for individual district courts over the years 2010-2013. It found a

\footnotetext{
72 The DeskboOk For Chief Judges of U.S. District COURTS (4th ed. 2014), published by the Federal Judicial Center, makes no mention of the E-Government Act's requirements in its section on statutory requirements or elsewhere. THE BENCHBOOK FOR U.S. DiSTRICT COURT JUDGES (6th ed. 2013) is equally silent.

73 This study has looked only at civil cases. An investigation of the tagging of opinions in district court criminal proceedings would, in all likelihood, reveal a similar spread.
} 
range spanning from a high of $76.6 \%$ in the Southern District of New York to a low of $20.8 \%$ in the Eastern District of Arkansas. ${ }^{74}$

Situated precisely at the median, $41.4 \%$, is the Middle District of Florida. ${ }^{75}$ According to the authors, these differential rates persist over time. ${ }^{76}$ Applying the $41.4 \%$ rate to the Middle District of Florida's Social Security case volume for 2016, together with national data on dismissals and voluntary remands sought by the government, produces an estimate of 348 remands (including 127 voluntary remands), 413 decisions upholding the agency decision, and 85 dismissals. Judges of the Middle District of Florida deal with voluntary remands and many dismissals without a level of explanation meeting the Judicial Conference definition of "written opinion". Putting those cases to one side, leaves a total of 637 Social Security cases in which one would expect there to be at least one written opinion. In many one would expect more. Cases where the parties have not consented to final disposition by the magistrate judge should have a minimum of two, a report and recommendation and separate adopting order. Successful appeals often bring a subsequent petition for attorney fees under the Equal Access to Justice Act. When that occurs the court must respond with another opinion (two if there is a magistrate's report and recommendation). In fact, only 463 Middle District of Florida Social Security cases generated documents logged as "written opinions" in the court's CM/ECF system during 2016. (The total number of those documents equaled 692.) In 63 of those cases, the only document appearing in the Written Opinions Report is a form signed by a deputy clerk noting the final judgment. All 63 are cases in which the judge's opinion or report and recommendation supporting and directing the entry of that judgment was not tagged. The totals suggest that at an absolute minimum one-third of the written opinions in this district's Social Security cases were not designated as such. They are, as a consequence, effectively hidden from public view.

The district's failures to tag do not distribute evenly across judges and divisions. Only six of the fifty-one closed cases that Judge Porcelli disposed of on the merits in 2016 appear in PACER's Written Opinions Report. Those six dramatically underrepresent his propensity to affirm the agency decision $(84 \%){ }^{77}$ Only three opinions by Magistrate Judge Thomas G. Wilson of the Tampa division show up on the Written Opinions Report, two of them reversing and remanding the administrative determination. Unreported are his additional twelve reversals and fifteen affirmances. Magistrate Judge Thomas B. McCoun III filed a total of twenty-nine opinions during 2016 that are not shown on the report. On the other hand, several magistrate judges from other divisions of the court appear to be meticulous in designating their opinions with that title and seeing that they are properly tagged. These include Judges Douglas Frazier, Carol Mirando, and Mac McCoy of the Fort Myer Division, and Judges James Klindt and Monte Richardson of the Jacksonville Division. Their practice remains consistent even when they are handling cases from another division. ${ }^{78}$

\footnotetext{
${ }^{74}$ ACUS Study, supra note 25, at 83.

75 See id. at 84.

76 See id. at $85,91,94$.

77 Those reported in full on the Written Opinions Report include four that affirm, two that reverse and remand. Only eight out the complete set of 51 reverse and remand.

78 Since Social Security appeals involve no hearings and usually no oral argument it is not difficult for magistrate judges of one office to take on cases from another division of the same court.
} 


\section{B. Other Districts, Other Patterns}

At least one district court has assured the tagging of qualifying opinions by designating nearly all orders as opinions, even those that address routine procedural matters. That is the reason the U.S. District Court for the Eastern District of California has so high a ratio of opinions to closed civil cases. It designated 1985 documents as written opinions in the 435 Social Security cases it closed in 2016. These included orders granting and denying motions to proceed in forma pauperis, granting extensions of time to file briefs, and disposing of other seemingly routine matters in addition to those addressing the substance of the plaintiffs' appeals. This approach leaves no substantive opinions hidden, but it does shift the burden of separating wheat from chaff to the individual researcher (All tagged documents are transmitted to FDsys.) or third-party database service. In the light of constantly improving search and filtering software this appears a relatively minor inconvenience, far to be preferred to missing opinions.

The bottom of the 94-court opinion labeling curve is anchored by the U.S. District Court for the Southern District of Iowa. It closed 102 Social Security cases during 2016, of which only six had tagged written opinions. Those six opinions were all magistrate judge reports and recommendations, three written by one judge, two by another, and one by a third. The corresponding adopting orders were not tagged nor were the vast majority of orders furnishing a "reasoned explanation" for the resolution of individual Social Security appeals during 2016. ${ }^{79}$ These include five opinions by a single senior judge published in the Thomson Reuters Federal Supplement series, presumably having been transmitted directly by the judge's chambers. ${ }^{80}$ These do not show up on the court's written opinions report. They are also missing from the small collection of opinions at the court's web site ${ }^{81}$ and from CourtWeb to which the district seems to have ceased contributing in $2014 .^{82}$

Lying between these extremes are districts in which the judges and court staff manage to apply the "written opinion" definition carefully and consistently. The U.S. District Court for the Middle District of Alabama closed 87 Social Security cases in 2016. All but six featured at least one tagged written opinion. Those six included three that were remanded upon the government's unopposed motion for the cases' return to the agency, one in which the plaintiff moved for a voluntary dismissal, one upon the case being transferred to another district, and the last a dismissal for the plaintiff's failure to file a brief. All opinions by the district's five magistrate judges that dealt with the

\footnotetext{
79 Those not tagged include Judge Charles Wolle's two-page opinion explaining his affirmance of the denial of SSI benefits to Adam Hessenflow. Hessenflow v. Commissioner of Social Security, No. 3:2015-cv-00032 (S.D. Iowa Feb. 5, 2016), http://www.access-to-law.com/pacer/SDIowa_15cv00032_02052016.pdf. Another is Judge Stephanie Rose's 26-page opinion reversing and remanding the Social Security Administration's decision denying Disability Insurance benefits to Brenda Prevett. Prevett v. Commissioner of Social Security, No. 4:2015-cv-00130 (S.D. Iowa April 5, 2016), http://www.access-to-law.com/pacer/SDIowa_15cv00130_04052016.pdf. 
merits of the district's 2016 Social Security cases were properly tagged as "written opinions". They can, therefore, be retrieved by PACER's Written Opinions Report and are readily available to the full range of case law database services, including the GPO's FDsys in which the district participates. The U.S. District Court for the District of Kansas closed 151 Social Security cases in 2016, 141 of them were disposed of by tagged written opinions. The remaining ten consisted of two dismissals and eight voluntary remands.

What the judges of these two districts have in common is an established practice of employing consistent terminology in the titling of opinions ("Opinion" in the case of the Middle District of Alabama, "Memorandum and Order" in the case of the District of Kansas). That facilitates docketing using CM/ECF events that have been programmed to result in automatic tagging.

Similarly, judges of the U.S. District Court for the Eastern District of Missouri use the label "Memorandum" to distinguish opinions that warrant tagging from routine orders. As a consequence, the practice recently adopted by one magistrate judge in the district has led to her opinions not being tagged. Her approach poses a novel question about the reach of the phrase "written opinion." During 2016 Magistrate Judge Shirley P. Mensah disposed of ten Social Security appeals by means of oral opinions, delivered to counsel following oral argument. Transcriptions of her opinions were filed in $\mathrm{CM} / \mathrm{ECF}^{83}$ These oral opinions refer with care to the parties' arguments and to the authorities they cite. Transcribed, they run to as many as eleven pages of "reasoned explanation." However, while the transcriptions, attached to final judgments, are available through PACER, they are not docketed as memoranda and thus not tagged as "written opinions." A 2016 Written Opinions Report for the Eastern District of Missouri misses them and the judgments to which they are attached, the majority of this one judge's Social Security decisions for the year. In all other respects, that report shows another court in substantial compliance with the "written opinion" requirement of the E-Government Act.

\section{Are Social Security Cases Representative?}

Correspondence between Hyperlaw's Alan Sugarman and the Administrative Office of the U.S. Courts dating back to 2008 documents a persistent opinion designation problem cutting across types of district court litigation. ${ }^{84}$ A recent article by Elizabeth McCuskey reports the hidden opinion phenomenon, which she terms "submerged precedent," in federal-question removal decisions. In a sample drawn from two districts, she found that nearly 30\% of the relevant "reasoned decisions" were invisible to anyone relying on the commercial databases. They were accessible through PACER, but only to those who knew of their existence or were prepared to dig through docket entries. ${ }^{85}$ In order of magnitude, her finding is comparable to this study's estimate of the "submerged" Social Security opinions rendered by judges of the Middle District of Florida. Another source reports a significant and continuing failure to tag opinions in EEOC litigation. ${ }^{86}$

\footnotetext{
83 See, e.g., Sanders v. Soc. Sec. Admin., No. 1:14-cv-00169-SPM (E.D. Mo. Mar. 1, 2016). http://www.access-tolaw.com/pacer/EDMo_14cv00169_03012016.pdf; VanDeven v. Colvin, 1:15-cv-00094-SPM (E.D. Mo. July 20, 2016), EDMo_14cv00094_07202016.pdf.

${ }^{84}$ Letter from Alan D. Sugarman to James C. Duff, July 10, 2009 with attachments, http://www.hyperlaw.com/topics/2009/2009-07-10-sugarman-to-ao-with-attachments.pdf.

${ }^{85}$ Elizabeth Y. McCuskey, Submerged Precedent, 16 NEV. L.J. 515, 530-31 (2016).

${ }^{86}$ E-mail from Nina Steinbrecker Jack, Fastcase, June 22, 2017 (copy on file with author).
} 
The stakes are atypically high with Social Security cases due to Rule 5.2(c) of the Federal Rules of Civil Procedure. Privacy concerns prompted this provision, which limits remote electronic access (i.e. PACER access) to the docket entries and documents in all "actions for benefits under the Social Security Act." It also applies to a variety of immigration cases. Exempt from the rule and therefore open to remote access is the court's "opinion, order, judgment, or other disposition" in cases that it covers. Because of Rule 5.2(c), unless the report and recommendation in a Social Security case is tagged as a "written opinion" it will remain unavailable through PACER even though adopted in full by a district judge order. When that occurs the failure to tag properly results in online access being blocked completely, rather than the imposition of a per page fee and omission from PACER's "Written Opinions Report." Thirteen instances of this extreme form of inaccessibility are to be found in the 2016 Social Security cases disposed of by the Middle District of Florida.

\section{A Few Conclusions}

\section{A. This Is Not a Small Problem}

During 2016, twenty-nine district courts had ratios of tagged opinions to closed civil cases below that of the Middle District of Florida, a demonstrably low standard. Two-thirds of the districts had ratios lower than 1.0, a plausible rough estimate of the average number of opinions across all types of civil cases. Applying that estimate to the courts falling below 1.0 yields an estimated annual total of hidden opinions in civil cases greater than 130,000. A more conservative ratio of 70 yields an estimate still in excess of 66,000 , nearly half the projected number of opinions issued by the courts involved. Even for those who know about individual untagged opinions, the failure to comply carries a cost. Their retrieval from PACER will not be free but result in a charge of $\$ .10$ per page. ${ }^{87}$

\section{B. Hidden Opinions Pose a Serious Challenge to Those Carrying Out Empirical Studies or Attempting to Use Judicial Analytics}

The widespread failure to tag opinions of the U.S. district courts thoroughly and consistently compromises empirical studies that focus on the work of these courts and emerging systems of datainformed prediction and planning. That is true whether the immediate data source is a public one (PACER, FDsys, an individual court database) or a commercial service. All depend ultimately on document designations applied by opinion authors and court staff. At minimum, empirical work on the federal district courts requires a careful look at the completeness of the data for the court and even the judge in question. As matters now stand, with the majority of districts that cannot be accomplished without a laborious review of docket information. ${ }^{88}$

\section{Addressing the Problem Will Require More Than Infrequent Appeals to Individual Conscientiousness}

Improving access to district court decisions will depend ultimately on the federal judiciary's national bodies - the Judicial Conference, the Administrative Office of the Courts and the Federal Judicial

\footnotetext{
${ }^{87}$ A suit focusing on this aspect of the problem was filed against the federal government in November 2016. D'Apuzzo v. U.S., No. 16-cv-62769-RNS (S.D. Fla. filed Nov. 22, 2016).

${ }^{88}$ Some scholars have argued that empirical studies of district court judge decision-making should not be limited to written opinions, but involve docket analysis as well. See Pauline T. Kim, Margo Schlanger, Christina L. Boyd and Andrew D. Martin, Empirical Research on Decision-Making in the Federal Courts: How Should We Study District Judge DecisionMaking?, 29 WASH. U. J.L. \& POL'Y 83 (2009). 
Center - taking the matter seriously. Taking it seriously should include periodic audits of individual court compliance with the "written opinion" mandate and emphasis on this feature of the CM/ECF system in training materials for both judges and court staff. The CM/ECF software should be configured in all districts so that the filing of an order adopting the report and recommendation of a magistrate judge automatically tags both as written opinions. The software should also be configured to require a final review for opinions before a case is marked "closed" and to permit retrospective tagging when omissions come to light. Most effective would be a CM/ECF change reversing the default designation for all judicially authored documents that rule on party motions. Instead of requiring a special designation or some other affirmative step to indicate that a document is an opinion, tagging should be automatic unless the filer affirmatively indicates by choice of docketing event or response to a query that it contains a routine non-substantive order.

\section{Participation in FDsys Should No Longer Be Elective}

Now that all lower federal courts have fully operational CM/ECF systems, inclusion in the GPO's FDsys database ought to be system-wide. So long as the opinion database is run on an "opt in" basis it will remain incomplete. Court participation in the national PACER index is not optional. There is no sound reason for inclusion in FDsys to be. For the broad public, as distinguished from the legal professionals relying on PACER and large data brokers collecting and reselling data drawn from it, completing the GPO database of decisions is the only way to realize the full value of this public system. It is also the best way to assure an enduring national archive. That, combined with consistent tagging of opinions, might finally fulfill the promise of the written opinion mandate of the E-Government Act of 2002. 